\title{
Variation in seed morpho-physiological and biochemical traits of Java olive populations originated from Java, Bali, Lombok, and Timor Islands, Indonesia
}

\author{
DEDE J. SUDRAJAT ${ }^{1, \bullet}$, ICHSAN SUWANDHI ${ }^{2}$, ISKANDAR Z. SIREGAR ${ }^{3}$, ULFAH J. SIREGAR \\ ${ }^{1}$ Forest Tree Seed Technology Research and Development Center. Jl. Pakuan, Ciheuleut, Bogor 16143, West Java, Indonesia. \\ Tel./fax.: +62-251-8327768, `email: djsudrajatbtp@yahoo.com \\ ${ }^{2}$ Departement of Forestry Engineering, School of Life Sciences and Technology, Institut Teknologi Bandung. Jl. Raya Bandung-Sumedang Km 20,75, \\ Jatinangor, Sumedang 45363, West Java, Indonesia \\ ${ }^{3}$ Departement of Silviculture, Faculty of Forestry, Institut Pertanian Bogor. Jl. Ulin, Dramaga, Bogor 16680, West Java, Indonesia
}

Manuscript received: 9 April 2018. Revision accepted: 9 May 2018.

\begin{abstract}
Sudrajat DJ, Suwandhi I, Siregar IZ, Siregar UJ. 2018. Variation in seed morpho-physiological and biochemical traits of Java olive populations originated from Java, Bali, Lombok, and Timor Islands, Indonesia. Biodiversitas 19: 1004-1012. Java olive (Sterculia foetida L.) is one of the promising non-edible feedstocks for biodiesel production. Utilization of this tree species for plantation is limited due to knowledge gaps in many fundamental aspects of seed properties. The aim of the study was to determine the variation that may exist among java olive seed collected from Bogor, Palimanan, Tuban, Gilimanuk, Pemenang and Naioni populations, and to analyze correlations between one or many seed morpho-physiological and biochemical traits. Analysis of variance showed significant differences of seed morphological and biochemical traits, except for the germination capacity. Seed morphological traits were not significantly correlated with agro-climate factors, while some of biochemical traits revealed significant correlation with some agroclimate factors. Genotypic variance and genotypic coefficient of variation were higher for fruit length, fruit width, carbohydrate, fat, protein and oil contents, indicating higher genetic contribution on the variance of these traits. High heritability values combined with high genetic gain was found for protein content, fruit width and oil content, that revealed the characters having highly genetic origin with a good number of heritable components. Population clustering exhibited that most of the geographically distant population are genetically related. Pemenang population was found highly associated with oil content, indicating that the population have high potency to develop as the feedstocks for for biodiesel production.
\end{abstract}

Keywords: Sterculia foetida, biodiesel, genotypic, heritabilitas, oil content, phenotypic

\section{INTRODUCTION}

The diminishing supply of fossil fuels reserves and the growing environmental concerns have made renewable energy an attractive alternative source for the future (Demirbas 2009; Mahanta and Shrivastava 2011; Atabani et al. 2013). Biodiesel is a promising alternative fuel and can make a substantial contribution to the future energy demands of the domestic and commercial economies (Silitonga et al. 2013). Some forest tree species have been found to be suitable species for biodiesel and one of the most prospective is java olive (Sterculia foetida L.) that produced about $200-350 \mathrm{~kg}$ of seed per plant annually (Munarso 2010) with a total oil content of about 34\% (Kirtikar and Basu 1999). Moreover, the properties of the produced java olive oil methyl esters and all the measured properties are within the limits of ASTM D 6751 and EN 14214 specifications (Silitonga et al. 2013), and from emission and combustion characteristics, java olive methyl ester oil closely followed the standard of diesel oil (Devan and Mahalakshmi 2009). Engine running with biodiesel from java olive seed as fuel is $14.2 \%$ higher efficient than diesel fuel due to low frictional losses (Rao et al. 2015). Therefore, java olive oil is one of the promising non-edible feedstocks for biodiesel production.

Java olive is a large, straight, deciduous tree which can grow up to $40 \mathrm{~m}$ in height and $3 \mathrm{~m}$ in girth (diameter of trees is around 100-120 cm) (Vipunngeun and Palanuvej 2009). It is a wild plant and well adapted to tropical and subtropical area $\left(30^{\circ}\right.$ North Latitude to $35^{\circ}$ South Latitude). In Indonesia, the species is distributed on almost all islands, and it is often found in primer and secondary forest, rocky and sandy areas, and coastal areas (Lemmens et al. 1995). Java olive has good adaptability to variety of soil, but probably needs soils with sufficient moisture for optimum development (Orwa et al. 2009). The plant has an average life span of more than 100 years (Munarso 2010). The species produces timber for light constructions and various parts have bioactive compounds for medicine (Orwa et al. 2009) and insecticide properties (Orwa et al. 2009; Rani and Rajasekharreddy 2009).

Cultivation of java olive in Indonesia is still limited and only planted as garden filler plants and hedges (Lemmens et al. 1995). However, to increase the plantation area and biodiesel production, it is important to domesticate the species initiated by identifying suitable genotypes or populations of java olive bearing high oil-yielding seeds, including information of morphological, physiological, and 
biochemical characteristics of java olive seeds across wide range of populations. Population variation with respect to seed morphophysiological and biochemical traits has been studied in many species and locations, such as Garcinia kola in Cameroon (Kanmegne et al. 2010), Pinus wallichiana in India (Rawat and Bakshi 2011), Jatropa curcas in West Nusa Tenggara (Santoso 2011), Cedrus deodara in Jammu and Kashmir (Mughal and Thapliyal 2012), Pongamia pinnata in India (Kumari et al. 2013), and Anthocephalus cadamba in Indonesia (Sudrajat, 2016). In several tree species, significant correlations have been shown to exist between specific seed attributes and specific environmental and geo-climate factors (Ghildiyal et al. 2009; Tauchen et al. 2011). Such correlations help to identify the environmental factors influencing plant physiology and morphology.

Morphological traits are useful for preliminary evaluation because they facilitate fast and simple evaluation and can be used as a general approach for assessing genetic diversity among morphologically distinguishable accessions (Čolić et al. 2012). Morphological traits combined with physiological and biochemical traits were commonly applied for characterization accessions or populations (Kumari et al. 2013). With respect to java olive, there are still lack of baseline information on many important traits such particularly as morpho-physiological and biochemical traits. The objective of this study was to determine the variability of morpho-physiological and biochemical traits of java olive seeds from 6 populations, to analyze the correlation among traits, and to identify the most useful variables for discrimination among populations, and finally to detect relationships among populations. The study will help selection criteria for characters of interest within population traits as they are necessary for further genetic improvement program.

\section{MATERIALS AND METHODS}

\section{Materials}

Seeds originating from six populations were preidentified covering distribution areas of java olive in Bogor, Palimanan (West Java), Tuban (East Java), Gilimanuk (Bali), Pemenang (West Nusa Tenggara) and Naioni (East Nusa Tenggara). The information of geographic origin of seed collection locations were shown in Figure 1 and Table 1.

Table 1. Geo-climate origin of the studied populations

\begin{tabular}{|c|c|c|c|c|c|c|}
\hline \multirow[b]{2}{*}{ Geo-climate characteristics } & \multicolumn{6}{|c|}{ Population } \\
\hline & $\begin{array}{c}\text { Bogor, } \\
\text { West Java }\end{array}$ & $\begin{array}{l}\text { Palimanan, } \\
\text { West Java }\end{array}$ & $\begin{array}{c}\text { Tuban, } \\
\text { East Java }\end{array}$ & $\begin{array}{c}\text { Gilimanuk, } \\
\text { Bali }\end{array}$ & $\begin{array}{c}\text { Pemenang, } \\
\text { Lombok }\end{array}$ & $\begin{array}{l}\text { Naioni, } \\
\text { Timor }\end{array}$ \\
\hline Latitude $(\mathrm{S})$ & $6^{\circ} 35^{\prime} 43^{\prime \prime}$ & $6^{\circ} 41^{\prime} 50^{\prime \prime}$ & $6^{\circ} 55^{\prime} 04^{\prime \prime}$ & $8^{\circ} 11^{\prime} 16^{\prime \prime}$ & $8^{\circ} 24^{\prime} 09^{\prime \prime}$ & $10^{\circ} 15^{\prime} 19^{\prime \prime}$ \\
\hline Longitude (E) & $106^{\circ} 48^{\prime} 09^{\prime \prime}$ & $108^{\circ} 24^{\prime} 18^{\prime \prime}$ & $112^{\circ} 02^{\prime} 50^{\prime \prime}$ & $114^{\circ} 26^{\prime} 29^{\prime \prime}$ & $116^{\circ} 06^{\prime} 22^{\prime \prime}$ & $123^{\circ} 36^{\prime} 05^{\prime \prime}$ \\
\hline Altitude (m asl) & 260 & 20 & 42 & 10 & 17 & 230 \\
\hline Precipitation (mm/year) & 3500 & 2300 & 2600 & 1559 & 1722 & 1290 \\
\hline Temperature $\left({ }^{\circ} \mathrm{C}\right)$ & 26 & 26.7 & 27.1 & 27.2 & 27.2 & 27.4 \\
\hline Relative humidity (\%) & 83 & 77 & 74 & 73.9 & 74 & 73 \\
\hline
\end{tabular}

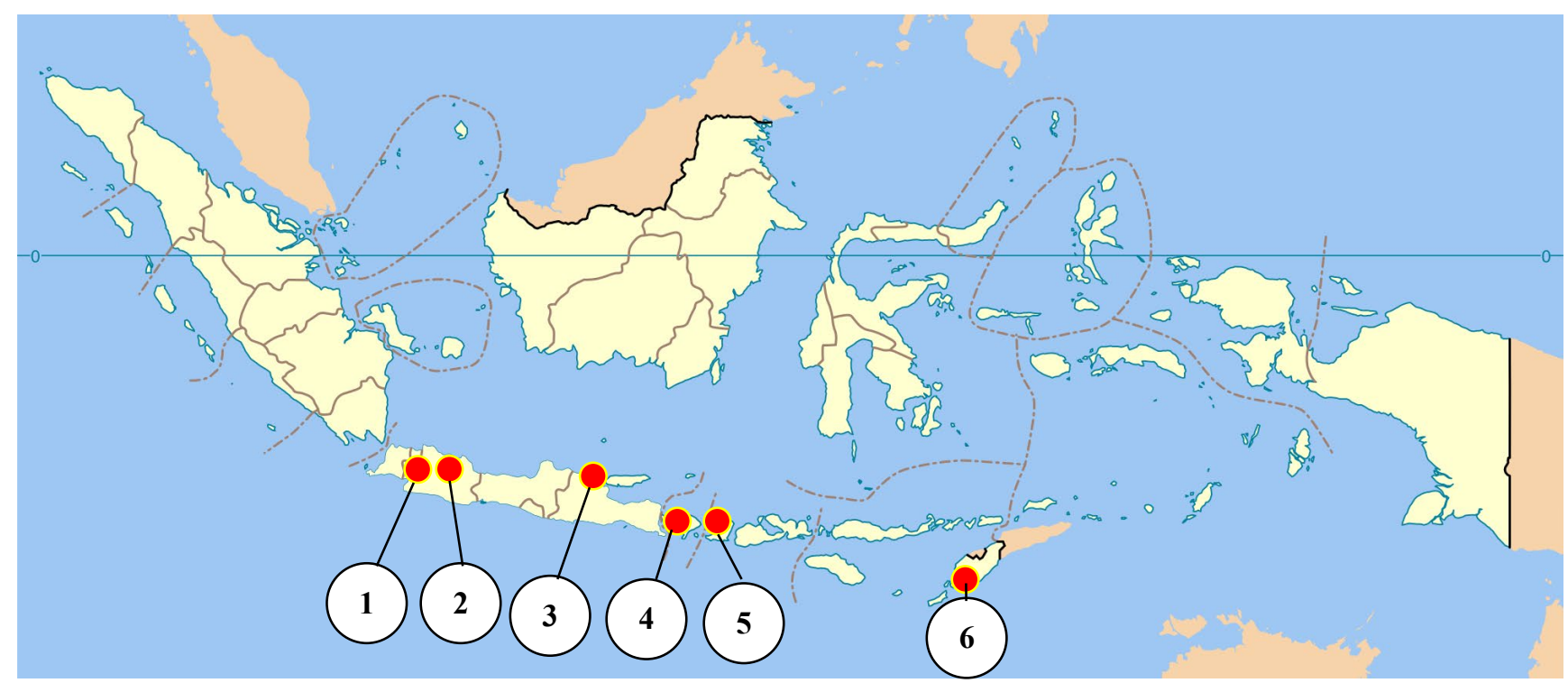

Figure 1. Samples distribution of Java olive in southern Indonesia. 1. Bogor (West Java), 2. Palimanan (West Java), 3. Tuban (East Java), 4. Gilimanuk (Bali), 5. Pemenang (West Nusa Tenggara), 6. Naioni (East Nusa Tenggara) 
Seeds at each of the location were collected from 10 average trees found about $50 \mathrm{~m}$ apart from each other in order to avoid family structure due to relatedness or inbreeding events. Seed processing was carried out in laboratory of seed technology, Forest Tree Seed Technology Research and Development Center, Bogor. Soil samples were taken from $20 \mathrm{~cm}$ depth from each site. Soil $\mathrm{pH}$, soil texture, soil nutrients, base saturation, and cation exchange capacity were analyzed at Soil and Plant Nutrition Laboratory, SEAMEO BIOTROP, Bogor.

\section{Morpho-physiological data}

The sampling method and design were the same for each population site. From each population, 200 undamaged fruits were randomly collected and measured for length and diameter of fruits (Rawat and Bakshi 2011). The seeds were extracted manually by cutting in half of fruits. The number of seed per fruit was counted. Equal weights of seeds composed the samples from individual trees, and seeds were bulked by population for the experiments. The seeds were dried in room condition (temperature $25-30^{\circ} \mathrm{C}$, relative humidity $70-80 \%$ ) for $4-5$ days before measurement (Sudrajat et al. 2011). One hundred and fifty (150) seeds from each of populations were measured for their length and width using a digital caliper. The same sample was also used to determine seed weight using weight digital scale (AR3130, Ohaus). Seed moisture content was determined by the constanttemperature oven method at $103 \pm 2^{\circ} \mathrm{C}$ for 17 hours (ISTA 2012).

Seed germination studies were carried out in greenhouse conditions (temperature $29-34^{\circ} \mathrm{C}$, relative humidity $60-75 \%$ ) using sand media with four replications of 100 seeds from each population. Seeds were treated by soaking in water for 24 hours before sowing, and then seeds were buried in the sand media in about $2 / 3$ part of the seed. A seed was considered to be germinated when a pair of leaves developed. Germination was assessed every 24 hours for 21 days, and data were recorded for germination capacity.

\section{Biochemical data}

The total crude oil content was determined using manual hot press hydraulic (Sudradjat et al. 2010; Handayani et al. 2015) at temperature $70^{\circ} \mathrm{C}$ for 1 hour. Pressing process was conducted two time to produce maximum yield. The oil produced by the process was weighed to measurement of oil content. For biochemical traits, two grams $(2.0 \mathrm{~g})$ of the seed sample were weighed and prepared for crude fat and protein analysis. Crude fat was determined based on the Soxhlet extraction method of AOAC (1990). Crude protein content was calculated using the Kjeldahl method. Total percentage carbohydrate was determined by the different method as reported by Onyeike et al. (1995).

\section{Stastistical analysis}

Seed morpho-physiological and biochemical traits were analyzed by using SPSS (version 21) for analysis of variance and Duncan multiple range test to determine the differences between populations. Linear correlation coefficients (Pearson) at 5\% level of significant were calculated among the studied characters and agro-climate factors (latitude, longitude, altitude, precipitation, temperature and relative humidity). Genotypic (GV), phenotypic (PV) and environmental variances (EV) were calculated using the following equations according to Burton (1952).

$$
\mathrm{GV}=(\mathrm{Mt}-\mathrm{Me}) / \mathrm{r} ; \mathrm{PV}=\mathrm{GV}+\mathrm{Me} ; \mathrm{EV}=\mathrm{Me}
$$

Where: $\mathrm{Mt}=$ mean square for treatments, $\mathrm{Me}=$ mean error variance, and $\mathrm{r}=$ number of replicates.

Phenotypic (PVC), genotypic (GVC), and environmental coefficients of variation (ECV) were calculated by using the formula as suggested by Burton (1952):

$$
\mathrm{PCV}=\sqrt{\mathrm{PV}} / \mathrm{x} ; \mathrm{GCV}=\sqrt{\mathrm{GV}} / \mathrm{x} ; \mathrm{ECV}=\sqrt{\mathrm{EV}} / \mathrm{x}
$$

Where: $\mathrm{x}=$ population mean for each trait

Heritability in broad sense $\left(\mathrm{H}^{2} \mathrm{~B}\right)$, the ratio of genetic variance to the total phenotypic variance, was estimated as suggested by Allard (1999). Genetic advance (GA) is the expected increase in the magnitude of a particular character when a selection pressure of chosen intensity (i) is applied.

$\mathrm{GA}=\mathrm{GV} / \mathrm{PV} \times \mathrm{i} \times \sqrt{\mathrm{PV}}$

Where: $\mathrm{i}=$ selection intensity $(2.06)$

Genetic gain (GG) expressed in percentage of mean was computed by using the formula given by Johnson et al. (1955). Hierarchical cluster analysis was used to explain the pattern of variation among the populations based on morpho-physiological and biochemical traits (Tomsone et al. 2012). Bi-plot analysis (Mustafa et al. 2015) was used to identify the performance and to cluster the java olive populations based on oil content and some key of seed morphological traits and geo-climate factors using SPSS (versi 22) for categorical principle component analysis.

\section{RESULTS AND DISCUSSION}

\section{Variation of morphophysiological and biochemical traits}

There were significant $(\mathrm{P}<0.05)$ differences in all of the morphological traits of fruit and seed of the populations. Bogor population showed higher values in all observed traits of fruit and seed morphological fruits (fruit length, fruit width, number of seed per fruit, seed length, seed width, and seed weight) (Table 2). Larger seed possibly due to a longer growing season (Totland and Birks 1996) and higher soil nutrition in Bogor population habitat (Table 3 ). Some studies reported a tendency for larger seed in drier habitats (Sorenson and Miles 1978; Stromberg and Patten 1990). The variation in fruit and seed traits among populations is probably due to influence of different intensities of natural constraints and also genetic factors. 
Significant variations in fruit and seed morphological traits were also reported in other studies, viz. Pinus wallichiana (Rawat and Bakshi 2011), Cedrus deodara (Mughal and Thapliyal 2012), Pongamia pinnata (Kumari et al. 2013), Jatropha curcas (Khadidiatou et al. 2013) and Anthocephalus cadamba (Sudrajat 2016).

Physiological seed trait (germination capacity) was not significantly different among populations indicating all populations had relative similar physiological trait with germination capacity ranged between $76.3-88 \%$. On the other side, all biochemical seed traits differed significantly $(\mathrm{P}<0.05)$ among populations. Bogor population provided the highest moisture content $(29.5 \%)$ and carbohydrate $(14.90 \%)$, while for fat content, Naioni population resulted the maximum value $(34.52 \%)$ followed by Pemenang population $(33.87 \%)$. The protein content was recorded maximum in Naioni population $(15.20 \%)$ followed by Gilimanuk population (14.40\%). The mean oil content varied from $17.54 \%$ (Bogor population) to $27.53 \%$ (Pemenang population) among the populations (Table 2). According to Sudradjat et al. (2010), oil content of java olive seed is about $25.5 \%$, lower than the seed oil content from Pemenang and Naioni populations in this study. Kale et al. (2011) reported the higher total oil of java olive seed that is about $32.4 \%$ on seed moisture content $9.2 \%$ and even Kirtikar and Basu (1999) stated that the oil content could reach $34 \%$. The lower oil content in this study could be caused by the high seed moisture content (17.1-29.5\%) and less effective of press manual hydraulic device to extract oil from the seeds. Sudradjat et al. (2010) recommended the extruder press mechanisms device to extract maximally seed oil content.

Fat was the highest biochemical composition (30.32\%) followed by oil (23.04\%), carbohydrate (12.84\%), and protein (12.84\%). Kavitha et al. (2015) reported the similar result that java olive seeds were rich in fat (30-36\%) and protein $11.4 \%$. Bureau of Plant Industry (BPI, 2010) also reported that the main compositions of java olive seeds are fats and protein which are $51.78 \%$ and $21.61 \%$ respectively. Variation in seed biochemical traits (carbohydrate, protein, fat) were observed in Pongamia pinnata (Jiang et al. 2013; Kumari et al. 2013) and Jatropha curcas ( (Kumar and Singh 2014). The seed biochemical contents in the selected genotypes also indicate towards some promising candidates for development and utilization in large scale plantation drives.

Table 2. Morphological traits of java olive fruit and seed from 6 populations

\begin{tabular}{|c|c|c|c|c|c|c|}
\hline Populations & $\begin{array}{c}\text { Fruit length } \\
\text { (cm) }\end{array}$ & $\begin{array}{l}\text { Fruit width } \\
\text { (cm) }\end{array}$ & $\begin{array}{c}\text { Number of seed } \\
\text { per fruit }\end{array}$ & $\begin{array}{c}\text { Seed length } \\
(\mathrm{mm})\end{array}$ & $\begin{array}{c}\text { Seed width } \\
(\mathrm{mm})\end{array}$ & Seed weight (g) \\
\hline Bogor & $14.76 \pm 0.85 \mathrm{a}$ & $13.47 \pm 0.73 \mathrm{a}$ & $15 \pm 2.33 \mathrm{a}$ & $28.3 \pm 2.3 \mathrm{a}$ & $16.4 \pm 3.6 \mathrm{a}$ & $4.05 \pm 0.52 \mathrm{a}$ \\
\hline Palimanan & $9.92 \pm 0.69 \mathrm{e}$ & $8.00 \pm 0.64 \mathrm{e}$ & $14 \pm 3.45 \mathrm{ab}$ & $25.7 \pm 0.7 \mathrm{bc}$ & $14.7 \pm 0.5 \mathrm{c}$ & $3.22 \pm 0.51 \mathrm{~b}$ \\
\hline Tuban & $12.13 \pm 0.55 \mathrm{c}$ & $11.45 \pm 0.56 \mathrm{c}$ & $15 \pm 1.69 \mathrm{a}$ & $25.4 \pm 1.1 \mathrm{c}$ & $13.7 \pm 0.8 \mathrm{e}$ & $2.89 \pm 0.64 \mathrm{c}$ \\
\hline Gili Manuk & $13.15 \pm 1.79 \mathrm{~b}$ & $12.25 \pm 1.20 \mathrm{~b}$ & $10 \pm 4.05 \mathrm{c}$ & $25.8 \pm 1.4 \mathrm{bc}$ & $14.7 \pm 0.9 \mathrm{c}$ & $3.31 \pm 0.36 \mathrm{~b}$ \\
\hline Pemenang & $10.33 \pm 1.18 \mathrm{e}$ & $9.47 \pm 0.89 \mathrm{~d}$ & $11 \pm 2.51 \mathrm{c}$ & $25.1 \pm 1.3 \mathrm{~d}$ & $14.2 \pm 0.6 \mathrm{~d}$ & $3.42 \pm 0.54 \mathrm{~b}$ \\
\hline Naioni & $11.03 \pm 0.85 \mathrm{~d}$ & $9.67 \pm 0.80 \mathrm{~d}$ & $13 \pm 1.91 \mathrm{~b}$ & $25.9 \pm 1.2 \mathrm{~b}$ & $15.3 \pm 1.1 \mathrm{~b}$ & $3.33 \pm 0.39 \mathrm{~b}$ \\
\hline F-test & $88.785^{* *}$ & $177.360 * *$ & $21.192 * *$ & $95.297 * *$ & $49.267 * *$ & $28.658^{* *}$ \\
\hline Range & $8.00-17.00$ & $6.50-15.00$ & $1-19$ & $18.14-36.95$ & $11.04-16.59$ & $2.01-4.87$ \\
\hline Mean & 11.89 & 10.71 & 13.43 & 26.04 & 14.84 & 3.37 \\
\hline SD & 1.98 & 2.02 & 3.48 & 1.76 & 1.82 & 0.61 \\
\hline CV $(\%)$ & 16.65 & 18.86 & 25.91 & 6.75 & 12.26 & 19.76 \\
\hline
\end{tabular}

Note: the data shown are mean \pm standard error of six replicates; Different letters a, b, c, d and e denote significant difference $(p \leq 0.05)$ between different treatments; **: Significant at $p<0.01$

Table 3. Soil fertility condition of 6 java olive population in this study

\begin{tabular}{|c|c|c|c|c|c|c|c|c|c|c|}
\hline \multirow[b]{2}{*}{ Populations } & \multicolumn{3}{|c|}{$\begin{array}{c}\text { Soil texture (SL-MU-TT-10, } \\
\text { Hydrometer) }\end{array}$} & \multirow{2}{*}{$\begin{array}{c}\mathrm{pH} \mathrm{H}_{2} \mathrm{O} \\
\text { (SNI 03- } \\
6787- \\
2002)\end{array}$} & \multicolumn{2}{|c|}{ Organic matter } & \multirow[b]{2}{*}{$\mathbf{C} / \mathbf{N}$} & \multirow{2}{*}{$\begin{array}{c}\text { P } \\
\text { (P2O5) } \\
\text { (SL-MU- } \\
\text { TT-05; } \\
\text { Bray I/II) }\end{array}$} & \multirow{2}{*}{$\begin{array}{c}\mathrm{K} \\
\text { (SL-MU-TT- } \\
\text { 07C: } \\
\text { Extraction of } \\
\text { buffer } \\
\mathrm{NH}_{4} \mathrm{OAc} 1,0 \mathrm{~N} \\
\text { pH 7,0) }\end{array}$} & \multirow{2}{*}{$\begin{array}{c}\text { KTK (SL- } \\
\text { MU-TT-07C: } \\
\text { Extraction of } \\
\text { buffer } \\
\mathrm{NH}_{4} \mathrm{OAc} 1,0 \mathrm{~N} \\
\text { pH 7,0) }\end{array}$} \\
\hline & $\begin{array}{r}\text { Sand } \\
(\%)\end{array}$ & $\begin{array}{r}\text { Dust } \\
(\%)\end{array}$ & $\begin{array}{r}\text { Clay } \\
(\%)\end{array}$ & & $\begin{array}{c}\text { C (\%) } \\
\text { (SNI 13- } \\
\text { 4720-1998: } \\
\text { Walkey and } \\
\text { Black) } \\
\end{array}$ & $\begin{array}{c}\text { N (\%) (SNI } \\
\text { 13-4721- } \\
\text { 1998: } \\
\text { Kjeldah) }\end{array}$ & & & & \\
\hline Bog & 2 & 21.60 & & & 225 & & 7.3 & 24 & 98.00 & \\
\hline Palimanan & 4 & 30.67 & 0 & 6.7 & 3. & & 14. & 13 & 137.33 & \\
\hline Tuban & 30.67 & 41.33 & 28.00 & 6.96 & 1.6 & 0 . & 10.46 & 102.67 & 602.00 & 29.00 \\
\hline Gili Manuk & 54.67 & 28.33 & 17.00 & 7.83 & 2.02 & 0.16 & 12.41 & 13.00 & 694.33 & 23.17 \\
\hline Pemenang & 59.67 & 28.67 & 11.67 & 6.83 & 1.20 & 0.09 & 12.44 & 68.33 & 412.33 & 16.42 \\
\hline Naioni & 17.00 & 42.67 & 40.33 & 6.60 & 1.79 & 0.14 & 12.51 & 90.67 & 421.33 & 44.68 \\
\hline
\end{tabular}

Note: SNI: Indonesian national standard 
The highest coefficient of variation was recorded for number of seed per fruit $(25.91 \%)$, moisture content $(22.41 \%)$, seed weight $(19.76 \%)$ followed by protein $(19.09 \%)$ (Table 2 and Table 4). All of morphophysiological and biochemical traits of java olive seeds showed significant differences among populations, confirming the hypothesis that java olive possesses strong differentiation between its populations, and indicating the existence of genetic variability. The variation of seed morpho-physiological and biochemical traits may due to both internal (maternal, hereditary) and external (environmental) conditions operating at the time of seed development (Harper et al. 1970; Kaushik et al. 2007). Changes of environment during evolution the species, habitat fragmentation and excessive exploitation may lead to a low gene flow, which in turn resulted in the differences in seed morpho-physiological and biochemical traits among populations.

\section{Correlation among seed morpho-chemical traits and geo-climate factors}

Fruit length exhibited positive significant correlation with fruit width (0.977). Significant correlations were found between seed length and seed width (0.905). Seed weight also had significant correlarion with seed length $(0.856)$ and seed width (0.890). The correlation has been exposed previously by Bagchi and Dobriyal (1990) on Acacia nilotica, Rawat and Bakshi (2011) on Pinus wallichiana, and Sudrajat (2016) on Anthocephalus cadamba, indicating that the traits are interdependent on each other. Significant correlation among traits are main interest in the improvement activities, because the improvement of one trait my cause simultaneous effects in the other trait (Divakara et al. 2010). In biochemical seed traits, a strong negative relationship of fat content with moisture content $(-0.920)$ and carbohydrate $(-0.815)$ was revealed. Fat content of java olive seeds showed positive correlation with oil content (0.841). Oil content also revealed a negative significant correlation with moisture content (-0.919) (Table 5).

Table 4. Physiological and biochemical traits of java olive seed from 6 populations

\begin{tabular}{lllllll}
\hline \multicolumn{1}{c}{ Populations } & $\begin{array}{c}\text { Germination } \\
\text { capacity (\%) }\end{array}$ & $\begin{array}{c}\text { Moisture } \\
\text { content (\%) }\end{array}$ & $\begin{array}{c}\text { Carbohydrate } \\
(\%)\end{array}$ & Fat (\%) & Protein (\%) & Oil content (\%) \\
\hline Bogor & $76.3 \pm 5.7$ & $29.5 \pm 3.7 \mathrm{a}$ & $14.90 \pm 0.81 \mathrm{a}$ & $27.20 \pm 1.63 \mathrm{~b}$ & $11.50 \pm 0.89 \mathrm{~b}$ & $17.54 \pm 1.89 \mathrm{~d}$ \\
Palimanan & $88.0 \pm 5.6$ & $25.3 \pm 2.6 \mathrm{~b}$ & $14.72 \pm 0.78 \mathrm{a}$ & $27.97 \pm 2.08 \mathrm{~b}$ & $9.17 \pm 0.36 \mathrm{~d}$ & $19.17 \pm 1.26 \mathrm{~d}$ \\
Tuban & $85.0 \pm 11.5$ & $24.3 \pm 3.1 \mathrm{c}$ & $13.60 \pm 0.82 \mathrm{~b}$ & $28.67 \pm 2.40 \mathrm{~b}$ & $14.40 \pm 0.97 \mathrm{a}$ & $24.76 \pm 2.29 \mathrm{bc}$ \\
Gili Manuk & $81.0 \pm 14.1$ & $23.3 \pm 6.7 \mathrm{~d}$ & $13.77 \pm 0.23 \mathrm{~b}$ & $29.67 \pm 1.75 \mathrm{~b}$ & $9.87 \pm 0.28 \mathrm{~cd}$ & $23.30 \pm 0.81 \mathrm{c}$ \\
Pemenang & $80.0 \pm 11.7$ & $17.1 \pm 3.3 \mathrm{f}$ & $13.37 \pm 0.85 \mathrm{c}$ & $33.87 \pm 2.40 \mathrm{a}$ & $11.82 \pm 0.29 \mathrm{bc}$ & $27.53 \pm 0.96 \mathrm{a}$ \\
Naioni & $79.5 \pm 10.2$ & $19.9 \pm 1.4 \mathrm{e}$ & $9.73 \pm 0.53 \mathrm{~d}$ & $34.52 \pm 1.59 \mathrm{a}$ & $15.20 \pm 0.24 \mathrm{a}$ & $25.97 \pm 1.84 \mathrm{a}$ \\
& & & & & & \\
F-test & $0.665 \mathrm{~ns}$ & $4.968^{*}$ & $23.880^{* *}$ & $26.901 * *$ & $9.636^{* *}$ & $64.925^{* *}$ \\
Range & $61.0-93.0$ & $13.2-34.2$ & $9.10-15.90$ & $25.20-36.60$ & $8.70-15.60$ & $15.20-28.62$ \\
Mean & 81.62 & 23.2 & 12.84 & 30.32 & 11.99 & 23.04 \\
SD & 9.93 & 5.2 & 1.82 & 3.40 & 2.29 & 3.92 \\
CV (\%) & 12.17 & 22.41 & 14.17 & 11.21 & 19.09 & 17.01 \\
\hline N & & &
\end{tabular}

Note: the data shown are mean \pm standard error of six replicates, different letters a, b, c, $\mathrm{d}$ and e denote significant difference $(P \leq 0.05)$ between different treatments, $* *$ : significant at $p<0.01, *$ : significant at $p<0.05$, ns: not significant.

Table 5. Simple correlation (Pearson) between fruit and seed traits of java olive

\begin{tabular}{|c|c|c|c|c|c|c|c|c|c|c|c|}
\hline Parameters & FL & FW & NS & SL & SW & SWE & GC & MC & $\mathbf{C H}$ & FT & PT \\
\hline FW & $0.977^{* *}$ & & & & & & & & & & \\
\hline NS & 0.186 & 0.101 & & & & & & & & & \\
\hline SL & 0.784 & 0.656 & 0.457 & & & & & & & & \\
\hline SW & 0.569 & 0.415 & 0.244 & $0.905^{*}$ & & & & & & & \\
\hline SWE & 0.575 & 0.472 & 0.083 & $0.856^{*}$ & $0.890 *$ & & & & & & \\
\hline $\mathrm{GC}$ & -0.608 & -0.617 & 0.173 & 0.173 & 0.597 & 0.397 & & & & & \\
\hline $\mathrm{MC}$ & 0.671 & 0.541 & 0.635 & 0.635 & 0.765 & -0.772 & 0.005 & & & & \\
\hline $\mathrm{CH}$ & 0.314 & 0.270 & 0.186 & 0.186 & 0.303 & 0.238 & 0.222 & 0.611 & & & \\
\hline FT & -0.512 & -0.419 & -0.521 & -0.521 & -0.501 & -0.157 & -0.279 & $-0.920^{* *}$ & $-0.815^{*}$ & & \\
\hline PT & -0.020 & 0.069 & 0.307 & 0.307 & -0.107 & -0.236 & -0.247 & -0.311 & -0.734 & 0.492 & \\
\hline $\mathrm{OL}$ & -0.469 & -0.293 & -0.515 & -0.515 & -0.750 & -0.522 & -0.040 & $-0.919^{* *}$ & -0.646 & $0.841^{*}$ & 0.549 \\
\hline
\end{tabular}

Note: FL: fruit length, FW: Fruit width, NS: number of seed per fruit, SL: seed length, SW: seed width, SWE: seed weight, MC: moisture content, GC: germination capacity, $\mathrm{CH}$ : carbohydrate content, F: fat content, PT: protein, OL: oil content, ${ }^{* *}$ : significant at $p<$ 0.01 , * significant at $p<0.05$. 
Table 6. Simple correlation (Pearson) between fruit and seed traits studied and geo-climate factors

\begin{tabular}{lcccccc}
\hline \multicolumn{1}{c}{ Parameters } & $\begin{array}{c}\text { Latitude } \\
(\mathbf{S})\end{array}$ & $\begin{array}{c}\text { Longitude } \\
(\mathbf{E})\end{array}$ & $\begin{array}{c}\text { Altitude } \\
(\mathbf{m} \text { asl) }\end{array}$ & $\begin{array}{c}\text { Precipitation } \\
(\mathbf{m m} / \mathbf{y e a r})\end{array}$ & $\begin{array}{c}\text { Temperature } \\
\left({ }^{\circ} \mathbf{C}\right)\end{array}$ & $\begin{array}{c}\text { Relative humidity } \\
(\%)\end{array}$ \\
\hline Fruit length & -0.293 & -0.389 & 0.320 & 0.551 & -0.564 & 0.562 \\
Fruit width & -0.242 & -0.301 & 0.235 & 0.417 & -0.429 & 0.434 \\
Number of seed per fruit & -0.547 & -0.467 & 0.373 & 0.478 & -0.577 & 0.497 \\
Seed length & -0.328 & -0.492 & 0.602 & $0.871^{*}$ & $-0.855^{*}$ & $0.877^{*}$ \\
Seed width & 0.016 & -0.202 & 0.745 & 0.731 & -0.669 & 0.728 \\
Seed weight & -0.093 & -0.312 & 0.518 & $0.816^{*}$ & -0.719 & $0.820^{*}$ \\
Seed moisture content & -0.734 & -0.802 & 0.166 & 0.759 & $-0.842^{*}$ & 0.748 \\
Germination capacity & -0.358 & -0.210 & -0.619 & -0.340 & 0.228 & -0.365 \\
Carbohydrate & $-0.912^{*}$ & $-0.946^{* *}$ & -0.557 & 0.641 & -0.685 & 0.624 \\
Fat & $0.901^{*}$ & $0.918^{* *}$ & 0.231 & -0.636 & 0.740 & -0.618 \\
Protein & 0.468 & 0.609 & 0.554 & -0.408 & 0.391 & -0.362 \\
Oil content & 0.684 & $0.816^{*}$ & -0.140 & $-0.845^{*}$ & $0.891^{*}$ & $-0.822^{*}$ \\
\hline
\end{tabular}

Note: $* *$ : significant at $p<0.01, *$ : significant at $p<0.05$

Table 6 showed that all of seed morpho-physiological traits, moisture content and proteint had not significant correlation with latitude, longitude and altitude. Some significant correlations were shown between precipitation and seed length $(r=0.871)$ and seed weight $(r=0.816)$. Similar with precipitation, relative humidity revealed significant positive corelation with seed length $(\mathrm{r}=0.877)$ and seed weight $(\mathrm{r}=0.820)$. The lower precipitation intensity may reduce seed mass as a result acceleration in seed growth rate (dry matter accumulation) and reduction in the duration of seed filling (Weigand and Cueller 1981; Spears et al. 1997). In this study, temperature of maternal habitat also significantly correlated with seed length $(r=$ 0.855) (Table 6). According to Li et al. (2015), seed size and weight variation may be the result of temperature variation during seed development.

Some agro-climate factors also exhibited the significant correlation with biochemical traits of java oil seeds. Latitute and longitude were significantly correlated with carbohydrate and fat content. Carbohydrate and fat tend to increase on the southern and eastern java olive populations. Longitude also had negative significant correlation with oil content. The effect of geographic position on seed biochemical traits is accumulation impact of geoclimate factors incorrelation with seed adaptation and development. Temperature exhibited the negative significant correlation with seed moiture content. Temperature, relative humidity and precipitation also showed the significant correlation with seed oil content (Table 6). Population had higher precipitation produced seed with relative higher moisture content and lower oil content. Studies of oil content variation also were reported by some researchers such as in Jatropha curcas. Ginwal et al. (2004) reported highest oil content $(58.12 \%)$ in Chhindwara accession of $J$. curcas with less rainfall and moderately high temperature. In contrary, Khadidiatou et al. (2013) reported that the seeds from wet region (Bignona) in Senegal recorded the highest oil content. Other study reported by Santoso (2011) using the narrow habitat of $J$. curcas in West Nusa Tenggara, there was not significant different oil content among populations. In this study, the seed samples were collected from relative large distribution from West Java to East Nusa Tenggara with the result that the seed variation including oil content was significant.

\section{Coefficient of variation and heritability}

The genotypic variance and genotypic coefficient of variation were higher for several traits, such as fruit length, fruit width, carbohydrate, fat, protein and oil contents, compared with environment variance and environment coefficient of variance. The results indicated that the genotypic component provided the major contributions to the total variance of fruit and seed biochemical traits. The variability among genotypes is generally used to estimate the total genetic variation to determine the degree of genetic control for a particular character (Giwali et al. 2015). Genetic control on the biochemical traits (carbohydrate, protein, oil content) also has been observed for several provenances of Pinus wallichiana in India (Rawat and Bakshi 2011) and several candidates plus tree of $J$. curcas in Eastern India (Kumar and Singh 2014). On the other hand, variation of seed morpho-physiological traits (number of seed per fruit, seed length, seed width, seed weight, germination capacity, moisture content) was more controlled by environmental factors.

In tree improvement and selection of suitable tree species, heritability of a certain desirable characters is important consideration. Broad sense heritability is defined as the ratio of all of the genetic variation to the phenotypic variation (Zobel and Talbert 1984) and it is important in predicting the amount of genetic gain. The high heritability value reveals that the offspring has a greater chance of resulting an expression of the trait that is similar to the trait of the parents; contrarily, a low heritability indicates a lower level of similarity (Kumari et al. 2013). High predictions of heritability value suggested that these traits may serve as important genetic markers in estimation the selection of best individuals or provenances. The highest heritability was revealed by protein $(0.94)$, carbohydrate $(0.87)$, oil content $(0.85$ and fruit width (0.85). High heritability values combined with high genetic gain was found for protein content, fruit width and oil content, 
revealed the characters have highly genetic origin with a good amount of additive genetic effect (heritable components). Rawat and Bakshi (2011) explained that high heritability value coupled with high genetic gain on some characters is important information for selecting the best population. Conversely, some characters such as seed length, seed width and germination capacity had lower genotypic coefficient of variance and genetic gain indicating that the contribution of non-additive genetic effects were higher than additive genetic effect.

\section{Population clustering}

Morphological characterization combined with multivariate statistical methods, such as cluster analysis, are useful tools for screening accessions (Akintobi et al. 2002; Golparvar 2013; Adebisi et al. 2013). Hierarchical cluster analysis separated the java olive populations based on the fruit, seed morphological and biochemical characteristics into three groups, i.e. Group 1: Pemenang and Naioni, Group 2: Tuban, Gilimanuk and Paliman, and Group 3: Bogor. The geographically distance among populations affected to the similarity of morphological and biochemical traits of java olive and belonging in the same cluster (Figure 2). Pamenang and Naioni populations lied in same cluster as representation of eastern populations of Indonesian java olive with higher seed oil content and lower seed moisture content. Some populations might be formed a mixture population such as Palimanan, Tuban, and Gilimanuk populations might be the mixture populations as a result of seed or genetic materials transfer among populations, whereas the Bogor population was separated from other populations representing the true population from relative wet site in western Java island.

Table 7. Mean coefficient of variability and genetic estimates of seed traits of java olive

\begin{tabular}{|c|c|c|c|c|c|c|c|c|c|}
\hline Parameters & GV & $\mathbf{E V}$ & PV & PCV & ECV & GCV & $\mathbf{H}^{2} \mathbf{B}$ & GA & GG\% \\
\hline Fruit length & 3.36 & 1.15 & 4.50 & 2.12 & 1.07 & 1.83 & 0.75 & 3.26 & 27.40 \\
\hline Fruit width & 4.08 & 0.69 & 4.77 & 2.18 & 0.83 & 2.02 & 0.85 & 3.84 & 35.90 \\
\hline Number of seed per fruit & 5.24 & 7.78 & 13.02 & 3.61 & 2.79 & 2.29 & 0.40 & 2.99 & 22.26 \\
\hline Seed length & 1.29 & 2.05 & 3.34 & 1.83 & 1.43 & 1.13 & 0.39 & 1.45 & 5.58 \\
\hline Seed width & 0.86 & 2.69 & 3.55 & 1.88 & 1.64 & 0.93 & 0.24 & 0.95 & 6.37 \\
\hline Seed weight & 0.13 & 0.15 & 0.28 & 0.53 & 0.38 & 0.36 & 0.46 & 0.50 & 14.54 \\
\hline Germination capacity & 8.91 & 106.43 & 115.34 & 10.74 & 10.32 & 2.99 & 0.08 & 1.71 & 2.09 \\
\hline Seed moisture content & 14.83 & 14.95 & 29.79 & 5.46 & 3.87 & 3.85 & 0.50 & 5.60 & 24.13 \\
\hline Carbohydrate & 3.26 & 0.50 & 3.77 & 1.94 & 0.71 & 1.81 & 0.87 & 3.46 & 26.97 \\
\hline Fat & 8.72 & 4.04 & 12.77 & 3.57 & 2.01 & 2.95 & 0.68 & 5.03 & 16.59 \\
\hline Protein & 5.67 & 0.35 & 6.02 & 2.45 & 0.60 & 2.38 & 0.94 & 4.76 & 39.68 \\
\hline Oil content & 14.76 & 2.58 & 17.34 & 4.16 & 1.61 & 3.84 & 0.85 & 7.30 & 31.69 \\
\hline
\end{tabular}

Note: GV: Genotypic variance, EV: environmental variance, PV: phenotypic variance, PCV: Phenotypic coefficient of variation, ECV: environmental coefficient of variation, GCV genotypic coefficient of variance, H2B: board sense heritability, GA: genetic advance, GG: genetic gain
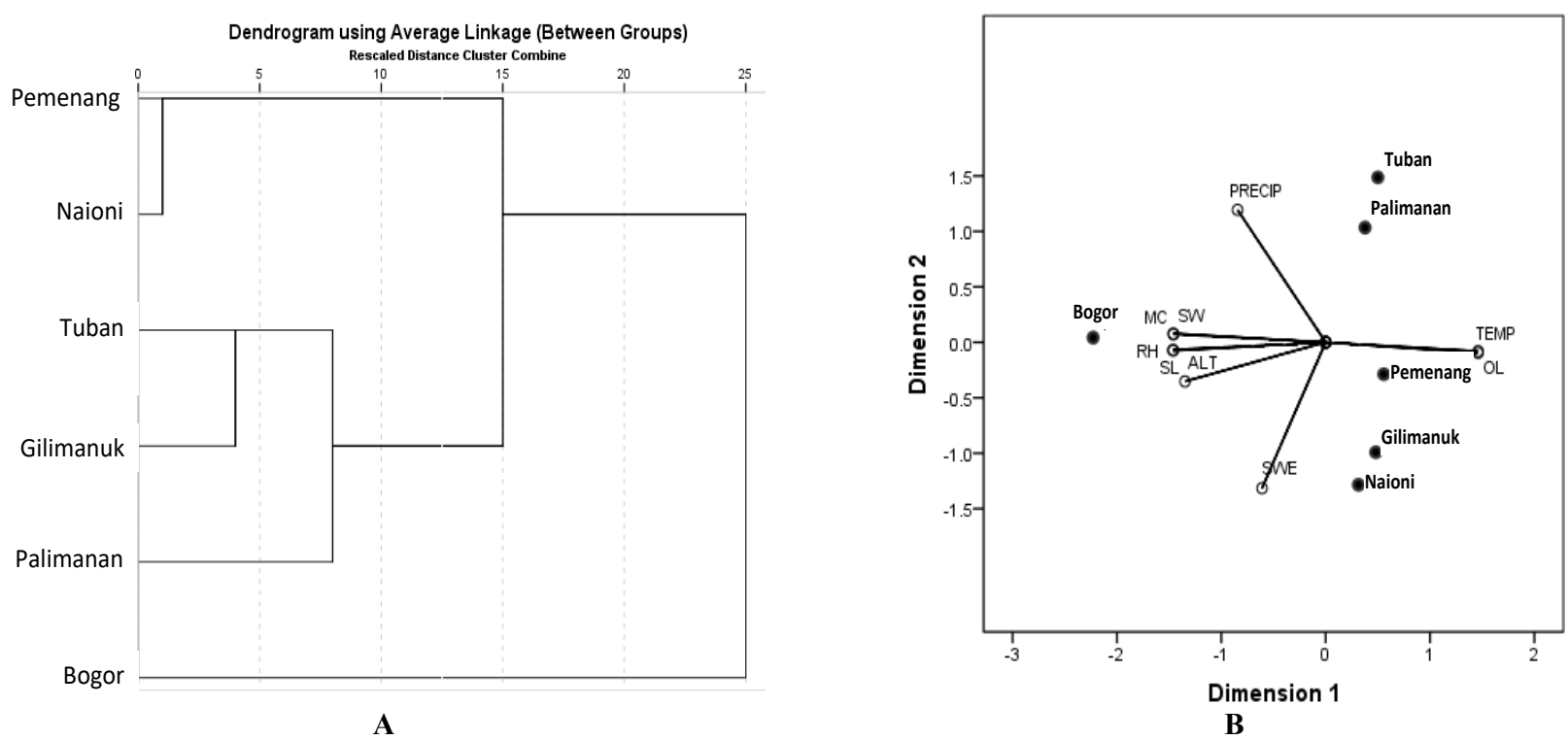

Figure 2. A. Cluster analysis graphical of 6 java olive populations based on fruit and seed morphophysiological and biochemical traits; B. Biplot of 6 java olive populations of seed width (SW), seed weight (SWE), seed length (SL), seed moisture content (MC), oil content (OL), altitude (ALT), precipitation (PRECIP), temperature (TEMP), and relative humidity (RH) 
The oil content, seed production and seed characters (e.g. seed size, width and moisture content) are the important parameters in the plant improvement program especially in the correlation with biodiesel production. In this study, the seed production was not analyzed because the population samples are the nature populations which has different age and stand density. Biplot analysis including some agro-climate factors (altitude, precipitation, temperature and relative humidity) combined by seed traits revealed that oil content formed obtuse angle with seed length, seed width, seed weight, and seed moisture content. The oil content also formed the obtuse angle with some agro-climate factors, such as altitude, relative humidity and precipitation, while as the sharp angle was formed by oil content and temperature. The obtuse angle revealed a negative correlation between characters, and conversely the sharp angle showed a positive correlation (Nurhasybi et al. 2009; Rohandi et al. 2017). Pemenang population associated with oil content, indicating the population have high trait of oil content, and opposite each other with Bogor population that have high seed length, seed width and moisture content. The characteristic of oil content is opposite with the seed size and weight and the information could be a consideration in selection of java olive in correlation with the oil content as material for biodiesel production.

This study had some weaknesses, such as limited number of populations, no metabolomic approaches using LCMS-GCMS etc. Nevertheless, for preliminary evaluation, the study could recommend the java olive potential population for biodiesel feedstock. Some populations such as Pemenang and Naioni had higher oil content that can become option populations for cultivation. Moreover, location of cultivation should be a consideration in relation with cost of production and appropriate environment for biodiesel production. According BPPESDM (2018), based on economic feasibility, development of renewable energy is more focused in outside of Java island because the local production cost of fossil oil in outside of Java island is higher than the national production cost. This study recommended that the java olive cultivation is carried out in Nusa Tenggara islands, such as Lombok and Timor islands.

\section{Conclusion}

Java olive from 6 populations in Java, Bali, Lombok and Timor islands exposed the diversity in seed morphological and biochemical traits. Seed morphological and biochemical traits revealed significant differences, except for the germination capacity. Most of seed morphological traits were not significantly correlated with agro-climate factors (except for seed lenght and seed weight), while some of biochemical traits (seed moiture content, carbohydrate, fat and oil content) revealed significant correlation with some agro-climate factors. Genotypic variance and genotypic coefficient of variation were higher for several traits, such as fruit length, fruit width, carbohydrate, fat, protein and oil contents, compared with environment variance and environment coefficient of variance, indicating that the genetic has the higher contribution on the variance of these traits. High heritability values combined with high genetic gain was found for protein content, fruit width and oil content, showed the characters have highly genetic origin with a good amount of additive genetic effect (heritable components). Hierarchical cluster analysis separated the java olive populations based on the fruit, seed morphological and biochemical characteristics into three groups, i.e. Group 1: Pemenang and Naioni, Group 2: Tuban, Gilimanuk and Paliman, and Group 3: Bogor. Pemenang population associated with oil content, indicating the population have high trait of oil content, and opposite each other with Bogor population that have high seed length, seed width and moisture content. It exhibited that the existence of substantial variation can be utilized for genetic resource conservation and further genetic tree improvement programs of the species.

\section{ACKNOWLEDGEMENTS}

We gratefully acknowledge the funding support from USAID through SHERA program, Center for Development of Sustainable Region (CDSR). The authors are grateful to the authorities of Environment and Forestry Research and Development Institute of Kupang, Indonesia and NonTimber Forest Product Research and Development Institute of Mataram, Indonesia for supporting in samples collection.

\section{REFERENCES}

Adebisi MA, Okelola FS, Ajala MO, Kehinde TO, Daniel IO, Ajani OO. 2013. Evaluation of variations in seed vigour characters of west african rice (Oryza sativa L.) genotypes using multivariate technique. Am J Plant Sci. 4: 356-363.

Akintobi DCA, Adebisi MA, Ojo DK. 2002. Multi- variate analysis of phenetic similarity of cowpea genotypes in different agro-ecological zones. Niger J Ecol. 4 (1): 18-23.

Allard RW. 1999. Principles of Plant Breeding. John Wiley \& Sons. New York. USA. P 254.

AOAC [Association of Official Analytical Chemists]. 1990. Official Methods of Analysis of the Association of Analytical Chemists. 15th ed. Arlington, Virginia, USA.

Atabani AE, Silitonga AS, Ong HC, Mahlia TMI, Masjuki HH, Badruddin IA, Fayaz H. 2013. Non-edible vegetable oils: A critical evaluation of oil extraction, fatty acid compositions, biodiesel production, characteristics, engine performance and emissions production. Renew Sustain Energy Rev. 18: 211-245.

Bagchi SK, Dobriyal JD. 1990. Provenance variation in seed parameters of Acacia nilotica. Ind J For. 116 (12): 958-961.

BPI [Bureau of Plant Industry]. 2010. Sterculia feotida Linn. Depertment of Agriculture. Government of Philippine. http Bureau of Plant Industry, Manila.

BPPESDM [Badan Penelitian dan Pengembangan Energi dan Sumber Daya Mineral]. 2018. Policy of Renewable Energy Development. Course on Bioenergy, Biorefenery and Energy Efficiency. Center for Development of Sustainable Regional. USAID-SHERA. Bogor, 4-6 April 2018.

Burton GW. 1952. Quantitative inheritance of grass. Proc. 6th Int. Grassland Cong. Held at Pennsylvania State College. PA,. USA.

Čolić S, Rakonjac V, Zec G, Nikolić D, Fotirić Akšić M. 2012. Morphological and biochemical evaluation of selected almond 
[Prunus dulcis (Mill.) D.A. Webb] genotypes in Northern Serbia. Turkish J Agric For. 36 (4): 429-438.

Demirbas A. 2009. Progress and recent trends in biodiesel fuels. Energ Convers Manag 50 (1): 14-34.

Devan PK, Mahalakshmi NV. 2009. Study of the performance, emission and combustion characteristics of a diesel engine using poon oilbased fuels. Fuel Process Technol. 90: 513-519.

Ghildiyal SK, Sharma CM, Gairola S. 2009. Environmental variation in seed and seedling characteristics of Pinus roxburghii Sarg. from Uttarakhand, India. Appl Ecol Env Res. 7 (2): 121-129

Ginwal HS, Rawat PS, Srivastava RL (2004). Seed source variation in growth performance and oil yield of Jatropha curcas Linn. in Central India. Silvae Genet. 53 (4): 76-80.

Golparvar AR. 2013. Probit analysis and heritability of salinity tolerance in agropyron desertorum genotypes. E J Biol. 9 (1): 15-18

Handayani R, Rukminita S, Gumilar I. 2015. Physico-chemical characterization of bintaro (Cerbera manghas L.) seed oil and its potency for biodiesel raw material. Jurnal Akuatika 6 (2): 177-186. [Indonesian]

Harper JL, Lovell PH, Moore KG. 1970. The shapes and sizes of seeds. Annu Rev Ecol Evol Syst 11: 327-356.

ISTA [International Seed Testing Association]. 2010. International rules for seed testing Edition 2010. The International Seed Testing Association, Bassersdorf.

Jiang Q, Yen S-H, Stiller J, Edwards D, Scott PT, Gresshoff PM. 2013. Genetic, biochemical, and morphological diversity of the legume biofuel tree Pongamia pinnata. J Plant Gen Sci. 1 (3): 54-67.

Johnson HW, Robinson HF, Comstock RF. 1955. Estimates of genetic and environmental variability in soybean. Agron J 47: 314-318.

Kale SS, Darade V, Thakur HA. 2011. Analysis of fixed oil from Sterculia foetida Linn. Intl J Pharmaceut Sci Res 2 (11): 2908-2914.

Kanmegne G, Mbouobda HD, Temfack B, Koffi EK, Omokolo DN, 2010. Impact of biochemical and morphological variations on germination traits in Garcinia kola heckel seeds collected from cameroon. Res J Seed Sci 3: 82-92.

Kaushik N, Kumar K, Kumar S, Kaushik N, Roy S. 2007. Genetic variability and divergence studies in seed traits and oil content of jatropha (Jatropha curcas L.) accessions. Biomass Bioenergy 31: 497-502.

Kavitha M, Vadivu R, Radha R. 2015. A review on Sterculia foetida Linn. Res J Pharmacog Phytochem. 7 (4): 239-244.

Khadidiatou NN, Mohameth K, Bassiaka O, Roger B, Ibrahima D. 2013 Variability in seed traits, oil content and genetic diversity in local and exotic accessions of Jatropha curcas L. in Senegal. African J Biotech. 12 (34): 5267-5277.

Kirtikar KR, Basu BD. 1999. Indian Medicinal Plants. Vol. 1. 2nd ed. Bishen Singh Mahendra Pal Singh, Dehradun, India..

Kumari K, Sinha A, Singh S, Divakara BN. 2013. Biochemical characterization and genetic diversity of Pongamia pinnata (L.) Pierre in Eastern India. J For Sci 29 (3): 200-210.

Kumar S, Singh S. 2014. Variability assessment of seed traits in Jatropha curcas L. for improvement of oil yield. Intl J Gen Mol Biol 6 (1): 815

Lemmens RHMJ, Soerianegara I, Wong WC. (Eds.). 1995. Plant Resources of South East Asia (Prosea). Timber trees: No. 5 (2). Minor Commercial Timbers. Backhuys Publisher, Leiden.

Li Z, Lu W, Yang L, Kong X, Deng X. 2015. Seed weight and germination behavior of the submerged plant Potamogeton pectinatus in the arid zone of northwest China. Ecol Evol 5 (7): 1504-1512.

Mahanta P, Shrivastava A. 2011. Technology develompment of bio-diesel as an energy alternative. In: Singh O, Pandey JP, Chauhan DS (eds.) Challenges and Strategies for Sistainable Energy Deficiency and Environment. New Age International, India.

Mughal AH, Thapliyal RC. 2012. Provenance variation in cone and seed characteristics of Cedrus deodara (D.Don) G. Don in Jammu and Kashmir. For Stud China 14 (3): 193-199.
Munarso J. 2010. Plantation of Sterculia feotida L. as vegetable oil. Information technology agriculture. Indonesia Agency for Agricultural Research and Development. Jakarta.

Nurhasybi, Sudrajat DJ, Diarta K. 2009. Identification of Acacia mangium provenances for solid wood forest plantation. J For Res 6 (1): 1-16.

Onyeike EN, Olungwe T, Uwakwe AA. 1995. Effect of heat treatment and defatting on the proximate composition of some nigerian local soup thickeners. Food Chem. 53: 173-175.

Orwa C, Mutua A, Kindt R, Jamnadass R, Simons A. 2009. Sterculia foetida L. Agroforestree Database: A Tree Reference and Selection Guide Version 4.0. World AgroforestryCenter, Nairobi, Kenya.

Rani PU, Rajasekharreddy P. 2009. Toxic and antifeedant activities of Sterculia foetida seed crude extract against Spodoptera litura and Achaea janata. J Biopestic 2 (2): 161-164.

Rao PV, Ramesh S, Kumar SA. 2015. Study of C I engine performance with diesel - biodiesel (Sterculia foetida) blend as fuel. Intl J Trend Res Dev 2 (4): 76-79.

Rawat K, Bakshi M. 2011. Provenance variation in cone, seed and seedling characteristics in natural populations of Pinus wallichiana A.B. Jacks (Blue Pine) in India. Ann For Res 54 (1): 39-55.

Rohandi A, Budiadi, Hardiwinoto S, Harmayani E, Sudrajat DJ. 2017. Variability in Morpho-physiology, Tuber Yield and Starch Content of Several Arrowroot Populations in Garut District. Agrivita J Agric Sci 39 (3): 311-323.

Saad H, Farooq J, Hasan E, Bibit T, Mahmood T. 2015. Cluster and principle component analysis of maize accessions under normal and water stress condition. J Agric Sci. 60 (1): 33-48.

Santoso BB. 2011. Variation in oil contents, and seed and seedling characteristics of Jatropha curcas of West Nusa Tenggara selected genotypes and their first improved population. Nusantara Biosci. 3 (3): $130-135$

Silitonga AS, Ong HC, Masjuki HH, Mahlia TMI., Chong WT, Yusaf T F. 2013. Production of biodiesel from Sterculia foetida and its process optimization. Fuel 111: 478-484

Sorenson FC, Miles RS. 1978. Cone and seed weight relationships in douglas-fir from western and cental Oregon. Ecology 59: 641-644.

Spears JF, Tekrony DM, Egli DB. 1997. Temperature during seed filling and soybean seed germination and vigour. Seed Sci Technol 25: 233244.

Stromberg JC, Patten DT. 1990. Variation in seed size of a southwestern riparian tree Arizona Walnut (Juglans major). Amer Midland Natur 124: $269-277$

Sudrajat DJ. 2016. Genetic variation of fruit, seed, and seedling characteristics among 11 populations of white jabon in Indonesia. Forest Sci Technol. 12 (1).

Sudrajat DJ, Nurhasybi, Syamsuwida D. 2011. Technology to improve kepuh (Sterculia foetida Linn.) seed viability. Jurnal Penelitian Hutan Tanaman 8 (5): 301-314. [Indonesian]

Sudradjat R, Yogie S, Hendra D, Setiawan D. 2010. Transesterification process for manufacturing kepuh seed biodiesel. Jurnal Penelitian Hasil Hutan 28 (2): 145-155. [Indonesian]

Tauchen J, Lojka B, Hlasna-Cepkova P, Svobodova E, Dvorakova Z, Rollo A. 2011. Morphological and genetic diversity of Calycophyllum spruceanum (Benth) K. Schum (Rubiaceae) in Peruvian Amazon. Agricultura Tropical et Subtropica, 44 (4): 212-218.

Tomsone L, Kruma Z, Alsina I, Lepse L. 2012. The application of hierarchical cluster analysis for classifying horseradish genotypes (Armoracia rusticana L.) roots. Chemine Technologija 4 (62): 52-56.

Totland O, Birks HJ. 1996. Factors influencing interpopulation variation in Ranunculus acris seed production in an alpine area of southwestern Norway. Ecogr 19: 269-278.

Vipunngeun N, Palanuvej C. 2009. Fatty acids of Sterculia foetida seed oil. J Health Res 23: 157.

Weigand CL, Cueller JA. 1981. Duration of grain filling and kernel weight of wheat as affected by temperature. Crop Sci 21: 95-101.

Zobel B, Talbert J. 1984. Aplied forest tree improvement. Waveland Press Inc. Illinois. USA. 